\title{
Characterization of Reproductive and Productive Performance of Indigenous and Crossbreed Dairy Cows in Angot District, North Wollo Zone, Ethiopia
}

\author{
Tarekegn Demeke \\ Collage of Agriculture, Department of Animal Science, Oda Bultum University, Chiro, Ethiopia \\ Email address: \\ tarekedeme@gmail.com \\ To cite this article: \\ Tarekegn Demeke. Characterization of Reproductive and Productive Performance of Indigenous and Crossbreed Dairy Cows in Angot \\ District, North Wollo Zone, Ethiopia. International Journal of Animal Science and Technology. Vol. 4, No. 3, 2020, pp. 62-69. \\ doi: $10.11648 /$ j.ijast.20200403.12
}

Received: October 4, 2020; Accepted: October 19, 2020; Published: October 23, 2020

\begin{abstract}
The study was undertaken in Angot district, North Wollo Zone, Ethiopia from June 2019 up to March 2020 . The objective of the study was of characterize the reproductive and productive performance of indigenous and crossbred dairy cow in Angot district. The participatory rural appraisal (PRA) method was used to generate information during exploratory survey and 100 households were selected for formal survey by using random and purposive sampling technique. The estimated daily milk yield of local and crossbred cow was found to be $1.32 \pm 0.11$ and $4.62 \pm 0.35$ liters, respectively. The mean lactation length for local and crossbred dairy cow were reported by the respondents were $9.15 \pm 0.63$ and $10.8 \pm 1.02$ months, respectively. The estimated lactation yield of local and crossbred dairy cow in the study area was $365.42 \pm 1.96$ and $1565.65 \pm 11.98$ liters, respectively. The average age at first service of local and crossbred dairy heifers in the study area was $34.5 \pm 2.71$ and $23.41 \pm 1.54$ months, respectively. The age at first calving (AFC) of the indigenous and crossbred was $45.13 \pm 2.31$ and $34.51 \pm 1.94$ months, respectively. The average calving interval of local and crossbred dairy cows in the study area were $18.38 \pm 1.05$ and $15.52 \pm 0.97$ months, respectively. The estimated average number of calf per lifetime of cow in the study area was $6.21 \pm 0.32$ (for local) and $9.59 \pm 0.49$ (for crossbred). The average reproductive lifetime of local and crossbred dairy cows in the study rea ware $16.21 \pm 0.27$ and $14.07 \pm 0.23$ years, respectively. The calculated reproductive efficiency of local and crossbred dairy cows were $46 \%$ and $77.53 \%$, respectively. In conclusion, the present study indicated that the reproductive performance of dairy cow in the study area was low, thus it calls attention to improve management system to improve the reproductive performance of dairy cows.
\end{abstract}

Keywords: Characterization, Dairy Cow Performance, North Wollo

\section{Introduction}

Agricultural sector of Ethiopia accounts for about $42 \%$ of the GDP, employs about $85 \%$ of the labour force, and contributes around $90 \%$ of the total export earnings of the country. The sector is dominated by over 15 million smallholders producing about $95 \%$ of the national agricultural production. Hence, the overall economy of the country and the food security of the majority of the population depend on smallholder agriculture [1, 2]. The livestock sector globally is highly dynamic. In developing countries, it is evolving in response to rapidly increasing demand for livestock products. In developed countries, demand for livestock products is stagnating, while many production systems are increasing their efficiency and environmental sustainability [3]. Ethiopia has the largest livestock inventories in Africa and this sector has a significant contribution to the country's economy and is still expected to support its economic development [4].

Underlying all animal breeding studies is the fact that neither all animals nor all breeds are equal. There are different aspects of management including differences within and between breeds in production, reproduction, fertility, size, disease resistance and the ability to withstand stress [5]. The indigenous breeds of tropics are attributed to natural selection to the tropical environment and management. They are well 
known for their adaptability, hardiness, disease resistance, heat tolerance, low feed supply and low management level. However, lack of understanding of the farming systems, prevailing constraints, and prospects of possible interventions in line with the socio-economic scenarios of the farmers constitutes by itself the fundamental problem for the development of the livestock sub-sector in Ethiopia [6]. Performance record of local cows is essential for designing breeding as well as managemental strategies develop the dairy sector [7]. In Ethiopia number of exotic and hybrid cattle is extremely low. This suggests that the total number of both exotic and hybrid female cattle produced through the crossbreeding work for many decades in the country is quite insignificant indicating unsuccessful crossbreeding work. This again suggested that Ethiopia needs to work hard on improving the work of productive and reproductive performance of cattle through appropriate breeding and related work most important factor that is a prerequisite for sustainable performance improvements of cattle through appropriate dairy production system and influencing the productivity breeding and related activities [5]. Therefore for better improvement of local cow, sustainability of improvement, easy and cost wise improvement, understanding of production and reproductive status of local cow is first and ever needed step in animal improvement area particularly in Ethiopia which has huge livestock population but couldn't meet animal protein demand ever increasing. Thus the current survey result was conducted to generate baseline data on production and reproductive performance of local cow in Angot district, North Wollo Zone, Ethiopia.

\section{Materials and Methods}

Description of the study area

The study was conducted in Angot district, North Wollo Zone, Ethiopia. From September 2019 to Febrary 2020. Angot district is located at a distance of $50 \mathrm{~km}$ from Woldia and $571 \mathrm{~km}$ from Addis Ababa. The study area has an altitude ranges from 3500-4500 meter above sea level. The mean annual rainfall varying between $1201 \mathrm{~mm}$ to $1800 \mathrm{~mm}$; and the mean minimum and maximum annual temperatures of 15.1 and $27.5^{\circ} \mathrm{C}$, respectively. The study district has 11 Kebeles. Mixed crop-livestock farming system, involving the production of cereals different livestock species, is predominantly practiced [8].

Data required

The data that was generated by exploratory survey and secondary information includes; Attempts was made to identify; major farm and off-farm activities, current practices, perception of the system in which the farmers operate and also to identify exogenous factors (which influence production pattern and the links between them), endogenous factors (which influence production-decision at the household level and the manner in which each affect the other) and the constraints (which they perceive to be important and their attitude to risk).

Sampling procedure
By defining the boundary of a dairy shed based on the information collected during the informal diagnostic survey, the geographical distribution of these sampling units within the dairy shed was established. Resource constraints was decided, although sample size was sufficiently large to permit statistical analysis, financial, human resource and time constraints was taken in to account prior to sample selection and survey execution. When a prior knowledge of the size of the target population is poor, a random sample selection with a given sampling intensity may be difficult to obtain. It may then be preferable to sample purposively, i.e. sample using a sub-set of the population but whose characteristics are known and meet desired criteria [9].

Field instrument: At dairy shed level as a preliminary step of collecting information on the production to consumption system, secondary sources was reviewed and discussions was held with knowledgeable key informants. At household level it is anticipated that much of the information required for characterization of the production to consumption system was gathered through primary data collection at the household level.

The methodology proposed was multipurpose single visit survey method, which is a formal survey of a representative sample of dairy production units within the dairy shed. The sample size proposed is in the range 100 to 150 units [10]. Farmer-recall (over one year) techniques were used for collecting the production data. From literature review and considering the cost, time and resource limitations a total of 100 households were considered adequate from three rural kebeles for the formal survey interview. List of female and male households obtained from each rural kebele officials was used for random selection of the households for the formal interview. Random table was used for household selection. Hence, stratified proportionate random sampling or purposive sampling technique was used for the study.

Data collection

Both exploratory and diagnostic survey was used to generate qualitative and quantitative data for the study. To have an overall view of the farming system, an exploratory survey was carried out using checklists to discuss with farmers. The Participatory Rural Appraisal (PRA) was used to generate information during exploratory survey. Moreover, a rapid survey technique with key-informant interview method was used. Based onthe information generated through PRA, the questionnaire [9, 10] was used and record sheets were developed for the formal interview/diagnostic survey. Before starting the actual formal survey, developed questionnaires was pre-tested for the suitability of the study. Field observation was taken of respondent farmers in the sampling area. Details on animals were gathered from owner's interview. Each farmer's degree of perception towards the importance and priority of identified constraints and endogenous factors which influence production to consumption decision at household level was identified by using card sorting method. Critical problems and constraints was identified from secondary data and qualitative information obtained in the exploratory survey. 
Statistical methods

The statistical analysis to be used in the study was vary depending on the type of variables and information obtained. However, the quantitative data was described by descriptive statistics (percentage, mean comparison, mode, median, standard deviation, etc) using Statistical Package for Social Sciences [11]. Chi-square was employed when required to test the independence of categorical variables and to assess association between levels of categorical variables. Correlation and regression analysis was used to determine the significance of associations among categorical variables. The parameter which measures reproductive efficiency could be calculated, the information gathered from the dairy owners based on, the number of calves born, age of cow in months and age at first breeding in months of dairy cows by using the following formula

$$
\text { Reproductive Effeciency }(R E)=\frac{12 x \text { Number of calves born }}{\text { age of cow in month }- \text { age at first breeding }+3} \times 100 \ldots
$$

Source: [13]

\section{Results and Discussion}

Based on the primary data collected during the household survey, the result and discussion part of this study gave more emphasis on productive performance (daily milk yield, lactation yield and lactation length) and reproductive performance (age at the first service, age at first calving, calving interval, number of calf per lifetime of cow, reproductive lifespan of breeding cows, reproductive efficiency of cows and major constraints of dairy cattle productivity.

Productive performance of local and crossbred dairy cows

Daily milk yield: Daily milk yield is a very important production efficiency trait, which is a combination of milk yield and lactation length. Cows with high milk yield per day of lactation length (MY/DLL) are cost-effective producers and have extra lactation milk yield. In the estimates of MY/DLL, milk yield on average basis of the lactation length were calculated by considering stages of lactation. As summarized in Table 1, the average daily milk yield of local and crossbred dairy cows in the study area was $1.32 \pm 0.11$ and $4.62 \pm 0.35$ liters, respectively. As compared with the previous finding, the current result was lower than the report of [12] who reported that, the daily milk yield of local and crossbred dairy cow in Chacha Town was1.67 and 4.73 liters, respectively. The daily milk yield of local cows in the current study area was equivalent to the daily milk yield of indigenous dairy cows in Alefadistret ( $1.30 \pm 0.05$ Liters $)$ and higher than Quara district (1.5 \pm 0.04 liters) [13].

Based on the information obtained during group discussion, the daily milk yield in the study area was is strongly affected by season of calving, stage of lactation and parity (age of the Dam). The current observed daily milk yield of local cow was lower than the report of [14] who reported that the overall daily milk yield of local cow in Dawro zone was $1.8 \pm 0.045$ liters. The milk yield of local cows of the study district are all most the same to local cow daily milk reported for different areas of local cattle of the country which is approximately with the range of 1.7 to 1.9 liters per day [15, $16,17]$. Milk yield per cow is 1.9 liters per day on average [18]. On the other hand [19] reported that national average milk yield from local cow per day is 1.37 which is almost equivalent tothe current finding. A Ministry of Finance and Economic Development (MoFED) report highlights that there is a significant productivity difference among local dairy breeds. The milk yield for local dairy breeds is about 1.5 liters per day per cow, which is about one-eighth of the milk yield ( 9 liters per day per cow) for improved dairy breeds [20].

Table 1. Daily milk yield of dairy cows in Angot district based on farmer's response in liters.

\begin{tabular}{|c|c|c|c|c|c|}
\hline Cow genotype & Stage of lactation & Mean \pm SE & Maximum & Minimum & Rang \\
\hline \multirow{4}{*}{ Local cows } & Beginning & $1.75 \pm 0.12$ & 3 & 1 & $1-3$ \\
\hline & Mid & $1.23 \pm 0.10$ & 2 & 0.75 & $0.75-2$ \\
\hline & Late & $0.98 \pm 0.09$ & 1 & 0.5 & $0.5-1$ \\
\hline & Average DMY & $1.32 \pm 0.11$ & 2 & 0.75 & $0.75-2$ \\
\hline \multirow{4}{*}{ Crossbred cows } & Beginning & $6.82 \pm 0.57$ & 9 & 4 & $4-9$ \\
\hline & Mid & $4.24 \pm 0.27$ & 6 & 3 & $3-6$ \\
\hline & Late & $2.79 \pm 0.21$ & 3 & 1.5 & $1.5-3$ \\
\hline & Average DMY & $4.62 \pm 0.35$ & 6 & 2.83 & $2.83-6$ \\
\hline \multirow{4}{*}{ Average } & Beginning & $4.29 \pm 0.35$ & 6 & 2.5 & $2.5-6$ \\
\hline & Mid & $2.74 \pm 0.19$ & 4 & 1.86 & $1.8-6-4$ \\
\hline & Late & $1.89 \pm 0.15$ & 2 & 1 & $1-2$ \\
\hline & Average DMY & $2.97 \pm 0.23$ & 3 & 1.79 & $1.79-3$ \\
\hline
\end{tabular}

Lactation length: Lactation length is an important production trait as it influences the total milk yield. In the majority of improved dairy farms, a lactation length of 305 days usually accepted as a benchmark. This standard allows for calving every 12 months with a 60-day dry period. The 12-month interval has considered "Ideal" for many years. If a cow milked longer than 305 days, her yield for the first 305 days taken as the lactation yield. Some cows are not milked for a full 305 days because they go dry or the lactation terminated for any of several reasons. These short records projected to a 305 days equivalent [21]. Based on the mean lactation length for local and crossbred dairy cow were 
reported by the respondents as $9.15 \pm 0.63$ and $10.8 \pm 1.02$ months, respectively (Table 2).

The current observed lactation length was higher thanprevious finding of [22] who reported mean lactation length of 255.75 days for local Ethiopian milking cows. Whereas the current lactation length local cows is higher by three months as compared to [19] who reported that average lactation period per cow during the reference period at country level about six months. But comparable with the report of lactation length reported by [23] who reported mean lactation length of 9.5 and $9.13 \pm 2.63$ months for native cattle in/ around Bahirdar. The current observed lactation length was lower than the report of [24] who reported that the overall lactation native dairy cows in Wolita zone was 10.80 +0.053 months. In general, Not only daily milk produced, lactation length is also one of factors that determine profitability of a given dairy cows owning individuals and productivity of a dairy cows as well. Most of the time Ethiopian dairy cow known by short period of lactation and long calving interval which shows that animal is being kept for long period of time without giving any products (milk and calf) and simply took feed and other cost of production.

Table 2. Lactation lengths of local and crossbred dairy cows in Angot district in months.

\begin{tabular}{|c|c|c|c|c|c|}
\hline Cow genotype & Stage of lactation & Mean \pm SE & Maximum & Minimum & Rang \\
\hline \multirow{5}{*}{ Local cows } & Beginning & $3.31 \pm 0.23$ & 5 & 2 & $2-5$ \\
\hline & Mid & $2.67 \pm 0.19$ & 4 & 2 & $2-4$ \\
\hline & Late & $3.17 \pm 0.21$ & 3 & 1 & $1-6$ \\
\hline & Total Lactation length & $9.15 \pm 0.63$ & 12 & 5 & $5-12$ \\
\hline & Beginning & $4.21 \pm 0.46$ & 7 & 3 & $3-7$ \\
\hline \multirow{2}{*}{ Crossbred cows } & Mid & $3.51 \pm 0.32$ & 5 & 2 & $2-5$ \\
\hline & Late & $3.08 \pm 0.24$ & 5 & 2 & $2-5$ \\
\hline \multirow{4}{*}{ Average } & Beginning & $3.76 \pm 0.35$ & 6 & 2.5 & $2.5-6$ \\
\hline & Mid & $3.09 \pm 0.26$ & 4.5 & 2 & $2-4.5$ \\
\hline & Late & $3.13 \pm 0.23$ & 5.5 & 1.5 & $1.5-5.5$ \\
\hline & Total Lactation length & $9.98 \pm 0.84$ & 16 & 6 & $6-16$ \\
\hline
\end{tabular}

Lactation yield: Performance of dairy cows could be judged from the milk it produces during a specified period of lactation. Variation observed in lactation milk yield from lactation to lactation in the same animal. The main cause of difference attributed to the physiology of lactation is the specified set of genes and their response with non-genetic factors. The lactation performance of dairy cattle is usually measured by determining total milk yield per lactation or per year, average daily milk yield, lactation length, persistency of milk production and milk composition. The estimated lactation yield of local and crossbred dairy cow in the study area was $365.42 \pm 1.96$ and $1565.65 \pm 11.98$ liters, respectively. The current result was higher than the report of [13] who reported that, the lactation yield of local cow was 329.6 and 348.8 litters, respectively in Alefa and Quara districts. The current results were higher than 277.2 litters for indigenous dairy cows at national level [25]. On the contrary, it was lower than $457.89 \pm 86.4$ litters reported for local cows in North Shoa Zone [12].

Table 3. Average lactation yield of cows based on farmer's estimation in litters in Angot district.

\begin{tabular}{|c|c|c|c|c|}
\hline Cow genotype & Stage of lactation & $\operatorname{Mean} \pm$ SE & Maximum & Minimum \\
\hline \multirow{4}{*}{ Local cows } & Beginning & $173.78 \pm 0.82$ & 450 & 60 \\
\hline & Mid & $98.52 \pm 0.57$ & 240 & 45 \\
\hline & Late & $93.12 \pm 0.57$ & 90 & 15 \\
\hline & Total lactation yield & $365.42 \pm 1.96$ & 780 & 120 \\
\hline \multirow{3}{*}{ Crossbred cows } & Beginning & $861.35 \pm 7.87$ & 1890 & 360 \\
\hline & Mid & $446.48 \pm 2.60$ & 900 & 270 \\
\hline & Late & $257.80 \pm 1.51$ & 450 & 90 \\
\hline \multirow{4}{*}{ Average } & Beginning & $604.38 \pm 4.35$ & 1080 & 187.5 \\
\hline & Mid & $272.5 \pm 1.59$ & 540 & 111.6 \\
\hline & Late & $175.46 \pm 1.04$ & 330 & 45 \\
\hline & Total lactation yield & $1052.34 \pm 6.98$ & 1950 & 344.1 \\
\hline
\end{tabular}

Age at first service: It is the age at which the breeding heifers reach for sexual maturity and accepting mating for the initial period. The economy of the farm can be feasible by showing estrous as early as possible for female animal [26]. The average age at first service of local and crossbred dairy heifers in the study area was $34.5 \pm 2.71$ and $23.41 \pm 1.54$ months, respectively. As compared with the previous finding, age at first service of local and crossbred dairy heifers in the current study area was contradicted with the report of [27] who reported that the age at first service (AFS) indigenous and crossbred cows in Endamehoni Districtwere 44.97 and 28.2 months respectively. Age at first service of crossbred dairy heifers in the current study area was slightly lower than with the results $[28,29]$ they reported that age at first service of crossbred was 24.9 months (range 18 to 36 months), 722.24 days and 24.30 months respectively. This might be due to the access of feed availability, heifer management during calf age with supplementation concentrate feeds 
during weaning age and genotype of the breeds.

Table 4. Ages at first service of local and crossbred dairy Heifers in Angot district based on farmers' response in months.

\begin{tabular}{lllll}
\hline Cow genotype & N & Mean & Minimum & Maximum \\
\hline Local cows & 72 & $34.5 \pm 2.71$ & 24 & 41 \\
Crossbred cows & 28 & $23.41 \pm 1.54$ & 17 & 36 \\
Average & - & $28.96 \pm 2.13$ & 20.5 & 38.5 \\
\hline
\end{tabular}

Age at first calving: First calving results the beginning of an indigenous cows for productive life and influences both the productive and reproductive life of the female, directly through its effect on life time calf crop and milk production and indirectly through its influence on the cost invested for up-bringing [30]. The age at first calving (AFC) of the indigenous and crossbred was $45.13 \pm 2.31$ and $34.51 \pm 1.94$ months, respectively (Table 5). The current finding was contradict with [27] who reported that the age at first calving
(AFC) of indigenous and crossbred cows in Endamehoni Districtwas 53.97 and 37.32 months, respectively. However, the present findings of AFC was lower from the results of [31] who reported 58.09 and 44.09 months for indigenous and crossbred dairy cows respectively in Adelinawereda of Oromia regional state of Ethiopia respectively. This variation might be due to feed availability, genetic level, access of concentrate feed, access of AI, dairy husbandry practices.

Table 5. Ages at first calving of local and crossbred dairy cows in Angot district based on farmers'response in months.

\begin{tabular}{lllll}
\hline Cow genotype & N & Mean \pm SE & Minimum & Maximum \\
\hline Local cows & 72 & $45.13 \pm 2.31$ & 35 & 52 \\
Crossbred cows & 28 & $34.51 \pm 1.94$ & 28 & 47 \\
Average & - & $39.82 \pm 2.13$ & 31.5 & 49.5 \\
\hline
\end{tabular}

Calving interval: The gap between two successive calving is called calving interval. Based the information obtained from the respondents, the average calving interval of local and crossbred dairy cows in the study area were $18.38 \pm 1.05$ and $15.52 \pm 0.97$ months, respectively (Table 6). The interval of local cows obtained in the present study longer than the previous CI reported by $[32,33]$ who reported that CI of $431.08 \pm 78.3$ days, $13.8 \pm 9$ months, 14.82 and 12.03 months for local cattle around MekeleTigray regional state, crossbred in Bishoftu area and cattle in highland of Bure districts oromia regional state and begaite cattle Amhara regional state, managed under small and large scale respectively. On the other hand CI higher than current study 54.1months [34], 54.1 months, [35] 54.7 [36], 26.6 \pm 06 and 18.72 \pm 0.5 months [37] for Kerrayu, Sheko, Wegera, and cattle around Gonder arearespectively was reportd. CI varies due to age of cows, breed of cows, calving season and forage availability in any particular year [38].

Table 6. The average estimated calving interval of dairy cows in Angot district in months.

\begin{tabular}{lllll}
\hline Cow genotype & N & Mean \pm SE & Minimum & Maximum \\
\hline Local cows & 72 & $18.38 \pm 1.05$ & 12 & 24 \\
Crossbred cows & 28 & $15.52 \pm 0.97$ & 12 & 17 \\
Average & & $16.95 \pm 1.01$ & 12 & 20.5 \\
\hline
\end{tabular}

Number of calf per lifetime of cow: number of calf per lifetime of cow is the most important economic trait especial for beef enterprises. It is a base line for calculating the reproductive efficiency of both local and crossbred dairy cows. As summarized in Table 7, the estimated average number of calf per lifetime of cow in the study area was $6.21 \pm 0.32$ (for local) and 9.59 \pm 0.49 (for crossbred).

Table 7. The average number of calf per lifetime of cow in Angot district.

\begin{tabular}{lllll}
\hline Cow genotype & N & Mean \pm SE & Minimum & Maximum \\
\hline Local cows & 72 & $6.21 \pm 0.32$ & 2 & 11 \\
Crossbred cows & 28 & $9.59 \pm 0.49$ & 3 & 13 \\
Average & - & $7.90 \pm 0.41$ & 2.5 & 12 \\
\hline
\end{tabular}

Reproductive lifetime of local and crossbred cows: As summarized in Table 8, the average reproductive lifetime of local and crossbred dairy cows in the study rea ware $16.21 \pm 0.27$ and $14.07 \pm 0.23$ years, respectively. The average reproductive lifetime of local in the current finding was higher than the report of [39] who reported that 11.5 years of lifetime for Bakko native cattle. Heard life productivity of
Ethiopian indigenous cattle is 11 to 13 years [29]. The difference in reproductive lifespan of cattle among the study could be management, breed age at first puberty and calving. The lifetime productivity of a cow is influenced by age at puberty, age at first calving and calving interval [40], genetic makeup and the health status of the cow [41] and management and feeding standards [42]. 
Table 8. The average Lifetime of local and crossbred dairy cows Angot district in in year.

\begin{tabular}{lllll}
\hline Cow genotype & N & Mean \pm SE & Minimum & Maximum \\
\hline Local cows & 72 & $16.21 \pm 0.27$ & 10 & 19 \\
Crossbred cows & 28 & $14.07 \pm 0.23$ & 8 & 17 \\
Average & - & $14.64 \pm 0.25$ & 9 & 17.5 \\
\hline
\end{tabular}

Reproductive efficiency of local and crossbred dairy cows in the study rea

The reproductive efficiency of dairy cow was calculated based on the information obtained from the respondents. The most important parametersused to measures reproductive efficiency dairy cow were the number of calves born, age of cow in months and age at first breeding in months of dairy cows. Based on such parameters and using the formula indicated at materials and methods part, the calculated reproductive efficiency of local and crossbred dairy cows were $46 \%$ and $77.53 \%$, respectively (Table 9). As compared with the previous finding, the reproductive efficiency of local cowwas lower than the report of [12] who reported that the reproductive efficiency of local breed dairy cow in north shoa was $62.1 \%$. However, the reproductive efficiency of crossbred dairy cow was higher than the report of [12] who reported that the reproductive efficiency of crossbred dairy cow in north shoa was $61.95 \%$.

Table 9. Calculated reproductive efficiency of local and cross-bred dairy cows in Angot district.

\begin{tabular}{lll}
\hline Cow genotype & N & Reproductive efficiency (\%) \\
\hline Local cows & 72 & 46 \\
Crossbred cows & 28 & 77.53 \\
Average & - & 63.32 \\
\hline
\end{tabular}

\section{Conclusion}

Productive and reproductive performances are the most important traits in animal production for economic benefit of producers and now a day it is worry of many countries with special emphasis in developing countries like Ethiopia. From the result, it can be concluded that crossbred cows were better than indigenous cow's in terms of their productive and reproductive performance improving the livelihood of smallholder farmers. From current survey results it can be also concluded that both productive and reproductive performance of local cow of the study area is very low and lag at the back of many African countries local cow productivity. The same to other part of the country, local cow (Angot cow) in the current study are characterized by low daily milk yield, long calving interval and longtime taken to reach age at first calving or longer age of puberty in short. But, on the contrary daily milk need of the country's population and price of one liter of milk is increasing dramatically every day.

Therefore, as matter of fact improvement of production and productivity of local cow by improving the feeding system, providing better health management, genetic improvement of local bred through crossbreeding to meet dramatically increasing need of milk yield and to cut off price of milk in order to make affordable cost by all classes of country's population is unquestionable agenda and the work that need collective effort by household, government and other concerned bodies too.

\section{Acknowledgements}

I would like to express my sincere appreciation to district Administration office and Livestock Development, Health and Marketing Agency and all staff members for providing the necessary baseline data for this study. I would like to appreciate and acknowledge the farmers who participated on the interview. I would also like to acknowledge the Development Agents in the study Peasant Associations for their critical support in data collection.

\section{References}

[1] Central Statistical Authority (CSA) (2015) Survey on livestock number in Ethiopia, the National Agricultural Statistics Service (NASS).

[2] Central Statistical Authority (CSA) (2016) Survey on livestock number in Ethiopia, the National Agricultural Statistics Service (NASS).

[3] Philip K. Thornton, 2010. Livestock production: recent trends, future prospects, Review. Phil. Trans. R. Soc. B (2010) 365, 2853-2867 doi: 10.1098/rstb. 2010.0134.

[4] Central Statistical Agency of Ethiopia (CSA). 2013. Agricultural sample survey. Report on livestock and livestock characteristics. The Federal an nDemocratic republic of Ethiopia, Central Statistical Agency (CSA). Private Peasant Holdings. Statistical Bulletin 570, Addis Ababa, Ethiopia, April, 2013.

[5] Kumar, Nirar, YemaneAbadi, BerihuGebrekidan and YohannesHagos Woldearegay. 2014. Productive and Reproductive Performance of Local Cows under Farmer's Management in and around Mekelle, Ethiopia. IOSR Journal of Agriculture and Veterinary Science (IOSR-JAVS) e-ISSN: 23192380, p-ISSN: 2319-2372. www.iosrjournals.org.

[6] Zinash, S., Aschaew, T., Alemu, Y. and Azage, T. 2001. Status of livestock research and development in the highlands of Ethiopia. PP. 227-250. In: P. C. Wall (eds.).

[7] Angot Woreda livestock and fishery office (2019).

[8] Rey B, Agyemang K, Thorpe W, Mullins G, Diedhiou M, Nokoe S, Shapiro B (1999). Market-oriented smallholder dairy research working document no. 4. A research methodology for characterising dairy production systems, ILRI (International Livestock Research Institute) Nairobi. Kenya.

[9] SPSS Version. 20.0. 2013. Software Package for Social Sciences for Window. 
[10] Mulugeta A and Belayeneh A. 2013. Reproductive and lactation performances of dairy cows in Chacha Town and nearby selected kebeles, North Shoa Zone, Amhara Region, Ethiopia. World J. Agri. 1 Sci. 1 (1): 008-017.

[11] Ayeneshet B, Abera M, Wondifraw Z (2018) Reproductive and Productive Performance of Indigenous Dairy Cows under Smallholder Farmers Management System in North. J Fisheries Livest Prod 6: 261. doi: 10.4172/23322608.1000261 .

[12] Taju H (2018) Productive and Reproductive Performance of Indigenous Ethiopian Cow under Small Household Management in Dawro Zone, Southern Ethiopia. International Journal of Current Research and Academic Review, 6 (5). doi: https://doi.org/10.20546/ijcrar.2018.605.007.

[13] Alganesh T. 2002. Traditional milk and milk products handling practices and raw milk quality in Eastern Wollega. M. Sc. Thesis.

[14] Gebrekidan T, Zeleke M and Gangwar SK. 2012. Reproductive and Productive Performance of Dairy Cattle in Central Zone of Tigray, Northern Ethiopia. I. J. A. B. R. 2 (1): 58-63.

[15] Wondossen Ayalew and Tesfaye Feyisa. 2017. Productive and reproductive performances of local cows in Guraghe zone, south west Ethiopia. Online Journal of Animal and Feed Research Volume 7 (5): 105-112.

[16] FAO. 2018. Africa sustainable livestock 20150: Livestock production systems spotlight Cattle sectors in Ethiopia. Pp111. FAO, 2018I8271EN/1/01.18.

[17] Central Statistical Agency of Ethiopia (CSA). 2017. Agricultural sample survey. Report on livestock and livestock characteristics. The Federal an nDemocratic republic of Ethiopia, Central Statistical Agency (CSA). Private Peasant Holdings. Statistical Bulletin 570, Addis Ababa, Ethiopia, April, 2013.

[18] Asfaw Negassa, Shahidur Rashid, BerhanuGebremedhin, and Adam Kennedy 2013.

[19] Wondifraw Z, Thomre BM, Bainwad DV (2013) Effect of non-genetic factors of milk production of Holstein Friesian $x$ Deoni crossbred cows. International journal of livestock production 4: 108-112.

[20] Belay Duguma 2012 Productive and reproductive performance and management practices of crossbred Dairy cow at Jimma College of agriculture and veterinary medicine dairy farm. International Journal of Current Research, 4, (1), 87-92.

[21] Lemma Fita, FikaduBeyene and Hegede B. 2005. Rural smallholders Milk and dairyproducts production, utilization and Marketing systems in East Shoa Zone o. f Oromia. In: Proceedings of the 12th Annual conference of the Ethiopian Society of Animal Production (ESAP) held in Addis Ababa, Ethiopia, August 12-14, 2004. ESAP, Addis Ababa, Ethiopia. Pp 29-37.

[22] Staal. SJ, Pratti. AN, Jabbar M. (2008) Dairy development for the resource poor part II. Kenya and Ethiopia. Deairy development studies, international livestock research institute.

[23] Belay DL (2016) Review on dairy dairy cattle breeding practice in Ethiopia. South agricultural research institute
(SARI). Hawassa agricultural research institute. Hawassa, Ethiopia. Journal of biology, agriculture and healthcare, Vol, 6 , 121-128.

[24] Mebrahtom and Hailemichael (2016) Comparative Evaluation on Productive and Reproductive Performance of Indigenous and Crossbred Dairy Cow Managed under Smallholder Farmers in Endamehoni District, Tigray, Ethiopia. Journal of biology, agriculture and healthcare, Vol. 6, No. 17, 2016.

[25] undumaDinka 2013 Reproductive performance of crossbred Dairy cow under smallholder condition in Ethiopia African Journal of dairy farming and milk production, 1 (5) 101-103.

[26] Haftamu Lemma, KelayBelihu and DessieShiferaw 2010 Study on the reproductive performance of Jersey cows at WolaitaSodo dairy farm, Southern Ethiopia WolaitaSodo University, Veterinary Journal, 14 (1), 53-70.

[27] Mukassa-Mugerewa, E 1989 A review of reproductive performance of female Bosindicus (Zebu) Cattle Monograph 6 ILCA (International Livestock Centre for Africa) Addis Ababa, Ethiopia.

[28] MulugetaAyalew 2005 Characterization of dairy production systems of yerer watershed in Ada libenworedaoromiya Regional State Msc. Thesis, Haramaya University, Haremaya, Ethiopia.

[29] Dereje Bekele. 2015. On Farm Phenotypic Characterization of Indigenous Cattle and Their Production Systems in BakoTibe and GobuSayo Districts of Oromia Region, Ethiopia. M. Sc Thesis. Haramaya University, Haramaya.

[30] Abdulai A., \& Huffman W. E. 2005. The Diffusion of New Agricultural Technologies: The Case of CrossbredCow Technology in Tanzania. American Journal of Agricultural Economics 87 (3), 645-659.

[31] Ensminger M. E. 1969. Animal science. Interstate Printers and Publishers, Danville, Illinois, USA. 1253 pp.

[32] Goshu G. 2005. Breeding efficiency, lifetime lactation and calving performance of Friesian-Boran crossbred cows at Cheffa farm, Ethiopia. Livestock Research for Rural Development. 17 (73).

[33] HJabbar Emmanuel Tambi, Mullins Gary (1997). Marketoriented smallholder dairying research working document No. 3. A methodology for characterizing.

[34] Dejene Takele. 2014. Assessment of Dairy Cattle Husbandry and Breeding Management Practices Lowland and MidHighland Agro-Ecologies Borana Zone. Animal and Veterinary Sciences, 2 (3): 62-69. doi: 10.11648/j.avs.20140203.

[35] Gebretnsae Mezgebe, Solomon Gizaw, Mengistu Urge and Arvind Chavhan. 2017. Begait cattle production systems and production performances in northern Ethiopia. Int. J. of Life Sciences. 5 (4): 506-516.

[36] Takele Taye, 2005. On-Farm Phenotypic Characterization of Sheko Breed of Cattle and their Habitat in Bench Maji zone, Ethiopia. M. Sc Thesis. Alemaya University, Ethiopia.

[37] Zewdu Wuletaw. 2004. Indigenous Cattle Genetic Resources, Husbandry Practices and Breeding Objectives in Northwestern Ethiopia. M. Sc Thesis presented to the School of Graduate Studies of Haramaya University, Haramaya, Ethiopia. 
[38] Mohammed Husen, Yisehak Kechero and Meseret Molla. 2016. Assessment of Livestock Feed Resources Utilization in Jimma Zone, Southwest Int. J. Curr. Res. Aca. Rev. 2018; 6 (5): 35-41, Ethiopia. Academic Journal of Nutrition. 5 (1): 0117.

[39] Endashaw Assefa. 2007. Assessment on production system and marketing of goats at Dale district, Sidama Zone. An MSc Thesis, Hawassa University, Ethiopia.

[40] Yifat D, Bahilibi W and Desie S. 2012. Reproductive Performance of Boran Cows at Tatesa Cattle Breeding Center. Advances in Bio. Res. 6 (3): 101105.
[41] Kebede H, Jimma A, Getiso A and Zelke B. 2017. Characterization of Gofa Cattle Population, Production System, Production and Reproduction Performance in Southern Ethiopia Journal of Fisheries \& Livestock Production. 5 (3): 1-12.

[42] Thornton, 2006. Mapping climate vulnerability and poverty in Africa. Nairobi, Kenya: ILRI. http://www.dfid.gov.uk/research/mapping-climate.pdf. 